\title{
Faktor Penentu Stunting: Analisis Komparasi Masa Millenium Development Goals (MDGs) dan Sustainable Development Goals (SDGs) di Indonesia
}

\author{
Sri Widari*, Nasri Bachtiar, Elvina Primayesa \\ Fakultas Ekonomi, Universitas Andalas, Padang, Indonesia \\ *Correspondence email: wida_zone@yahoo.com
}

\begin{abstract}
Abstrak. Penelitian ini bertujuan untuk menganalisis faktor penentu stunting melalui karakteristik rumah tangga,karakteristik ibu dan karakteristik anak sebelum dan sesudah agenda SDGs di Indonesia. Stunting adalah keadaan balita gagal tumbuh atau terlalu pendek bila dibandingkan dengan balita seusianya diakibatkan oleh penyebab langsung dan penyebab tidak langsung dan merupakan permasalahan gizi yang menjadi fokus pemerintah. Secara nasional angka prevalensi stunting di Indonesia pada akhir Millenium Development Goals (MDGs) tahun 2015 adalah 36,4\% dan tahun 2018 berdasarkan data Riskesdas sebesar 30,8\%. Angka ini masih berada diatas target RPJMN 2019 yaitu stunting 28\% dan ketetapan WHO yaitu prevalensi stunting 20\% di tahun 2025 serta 0\% stunting pada tahun 2030 sesuai target SDGs. Variabel yang dikaji dalam penelitian ini adalah akses air bersih, akses sanitasi, akses layanan kesehatan, jaminan kesehatan nasional, tempat tinggal, ibu dengan tinggi badan kurang, ibu dengan pendidikan pengasuhan, berat badan bayi saat dilahirkan dan kelahiran prematur. Kajian ini menggunakan data sekunder Riskesdas tahun 2013 dan 2018, diolah dengan regresi logistik. Hasil penelitian menunjukkan bahwa berat badan balita saat dilahirkan, ibu dengan tinggi badan kurang, tempat tinggal, akses sanitasi, akses air bersih dan kelahiran prematur memiliki hubungan bermakna (signifikan) terhadap kejadian balita stunting.
\end{abstract}

Kata kunci: Balita; MDGs; SDGs; Stunting

\begin{abstract}
This study aims to analyze, before and after the SDGs agenda in Indonesia, the determinants of stunting through household characteristics, mother characteristics and child characteristics. Stunting is a condition in which, due to direct and indirect causes, toddlers fail to thrive or are too short compared to children of their age and is a nutritional problem that is the government's focus. Nationally, at the end of the Millennium Development Goals (MDGs) in 2015, the prevalence rate of stunting in Indonesia was 36.4 percent and 30.8 percent in 2018. This figure is still above the RPJMN target for 2019, namely $28 \%$ stunting and the WHO stipulation, namely 20\% stunting prevalence in 2025 and $0 \%$ stunting prevalence in 2030 according to the SDGs target. Access to clean water, access to sanitation, access to health services, national health insurance, housing, underweight mothers, mothers with parental education, birth weight and premature births were the variables studied in this study. This research uses secondary data, processed with logistic regression, from Riskesdas in 2013 and 2018. Results showed that under-five birth weight, underweight mothers, shelter, access to sanitation, access to clean water and preterm birth had a significant (significant) association with the incidence of under-five stunting.
\end{abstract}

Keywords: MDGs; SDGs; Stunting; Toddlers

\section{PENDAHULUAN}

Kesehatan merupakan salah satu proses transformasi pembangunan mendasar yang berperan penting dalam pembangunan manusia. Keberhasilan pembangunan kesehatan berperan penting dalam meningkatkan mutu dan daya saing sumber daya manusia. Secara mikro ekonomi, kesehatan manusia merupakan modal dasar bagi produktivitas kerja. Manusia yang sehat tentu akan lebih produktif sehingga mudah dalam melakukan pekerjaan dan pada akhirnya memiliki penghasilan yang tinggi. Secara makro ekonomi, penduduk dengan tingkat kesehatan baik adalah input untuk menurunkan angka kemiskinan, meningkatkan pertumbuhan ekonomi dan terjadinya pembangunan jangka panjang di suatu negara (Elfindri, 2003).

Status gizi pada anak merupakan permasalahan kesehatan malnutrisi hampir di seluruh negara berkembang tidak terkecuali Indonesia. UNICEF (2019) menyatakan bahwa status gizi atau malnutrisi anak terdiri dari 3 (tiga) yaitu underweight merupakan kekurangan berat badan pada usianya, stunting adalah rendahnya rasio tinggi terhadap umur dan wasting yakni rendahnya rasio berat terhadap tinggi. Namun stunting menjadi permasalahan gizi anak paling tinggi saat ini. Stunting dianggap dapat menyebabkan rendahnya kapasitas intelektual anak, menurunkan daya saing dan kualitas sumber daya manusia di masa depan dan pada akhirnya memberikan dampak negatif terhadap perekonomian Indonesia (Bappenas, 2018).

Stunting adalah kondisi anak kekurangan gizi yang dapat dilihat ketika bayi masih dalam kandungan sampai dia lahir yang menyebabkan gangguan tumbuh kembang sehingga berubah menjadi anak dengan tubuh yang pendek untuk usianya. Hal ini sesuai dengan defenisi Kemenkes RI (2016) yang menyatakan bahwa balita stunting adalah balita berdasarkan umurnya dengan panjang badan $(\mathrm{PB} / \mathrm{U})$ atau tinggi badan $(\mathrm{TB} / \mathrm{U})$ dibandingkan dengan standar pertumbuhan anak yang dikeluarkan oleh WHO-MGRS (Multicentre Growth 
Reference Study) tahun 2005. Dalam rangka penurunan stunting difokuskan kepada penyebab langsung yaitu masalah gizi pada anak dan penyebab tidak langsung yang dipengaruhi oleh berbagai faktor, meliputi pendapatan dan kesenjangan ekonomi, perdagangan, urbanisasi, globalisasi, sistem pangan, jaminan sosial, sistem kesehatan, pembangunan pertanian, dan pemberdayaan perempuan (Bappenas, 2018).

Penurunan stunting ditargetkan pada Sustainable Development Goals (SDGs) tahun 2030. SDGs merupakan sebuah program pembangunan yang berkelanjutan dengan 17 tujuan (goals) dan 169 indikator yang terukur dan memiliki tenggat waktu pencapaian yang disahkan di New York dan mutlak menggantikan Millenium Development Goals (MDGs) yang berakhir pada tahun 2015. Darma et al (2020) mengungkapkan beberapa masalah yang belum teratasi sampai dengan masa MDGs berakhir, yaitu:

1. Masih terdapat disparitas jumlah rumah tangga miskin antara daerah pedesaan dan perkotaan.

2. Ketidaksetaraan gender masih ada.

3. Masih banyak terjadi konflik (peperangan) yang akan menghambat pembangunan manusia.

4. Kurangnya pelayanan dasar hingga masih banyak kemiskinan dan kelaparan.

5. Perubahan iklim dan degradasi lingkungan merongrong kemajuan yang diperoleh, dan kelompok masyarakat miskin terkena dampak yang paling besar.

Pada dasarnya MDGs dan SDGs memiliki persamaan tujuan, oleh karenanya SDGs menindak lanjuti tujuan MDGs yang belum terpenuhi terutama tujuan menghilangkan kemiskinan dan kelaparan. Mishra et al (2019) dalam penelitiannya menyebutkan bahwa 12 dari 17 tujuan (goals) SDGs secara langsung maupun tidak langsung adalah terkait dengan kekurangan gizi terutama pada tujuan (goals) kedua yaitu tanpa kelaparan (zero hunger). Komitmen negaranegara SDGs termasuk Indonesia dalam pembangunan berkelanjutan ini dimulai dari anak-anak yaitu dengan memastikan mereka dapat tumbuh bebas dari kemiskinan, dengan sehat terdidik, merasa bahagia dan aman yang merupakan dasar untuk menciptakan manusia dewasa yang dapat berkontribusi kepada ekonomi negaranya. Dalam hal ini kesehatan anak yang diprioritaskan adalah masalah penurunan prevalensi stunting.

Laporan Riskesdas (2018) menunjukkan angka prevalensi stunting di Indonesia pada tahun 2018 adalah $30,8 \%$. Angka ini masih jauh bila dibandingkan dengan target RPJMN 2019 yaitu stunting 28\% dan ketetapan WHO yaitu prevalensi stunting sebesar $20 \%$ di tahun 2025 serta $0 \%$ stunting pada tahun 2030 sesuai yang ditargetkan dalam SDGs. Indonesia memiliki tempat kedua setelah Kamboja pada tingkat Asia Tenggara (Global Nutrition, 2016) dan menduduki peringkat tiga
Asia untuk angka stunting balita, dibawah Timor Leste dan India (WHO, 2018). Terakhir dalam World Health Statistics 2019 yang dikeluarkan oleh WHO, Indonesia berada pada tingkat 25 terendah di dunia.

Teori investasi human capital bukan hanya dilihat dalam bentuk pendidikan, pelatihan dan pengetahuan, tapi juga dalam bentuk kesehatan (Becker, 1993;Todaro, 2000). Kesehatan mampu mempengaruhi peningkatan partisipasi tenaga kerja selanjutnya memperbaiki tingkat pendidikan dan kemudian menyumbang pertumbuhan ekonomi. Teori ekonomi kesehatan merupakan ilmu ekonomi yang diterapkan pada sektor kesehatan (Grossman, 1972; Tjiptoherijanto, 1994; Lubis, 2009). Aspek ekonomi seperti pendapatan merupakan syarat untuk menikmati fasilitas kesehatan seperti tersedianya sarana kesehatan, keadaan lingkungan yang memadai dan mutu makanan untuk di konsumsi (Puluhulawa, 2013; Munadhir, 2017).

Hubungan antara kesehatan dan pembangunan ekonomi dapat dilihat berdasarkan tingkat mikro yaitu tenaga kerja yang sehat secara fisik dan mental akan lebih produktif dan mendapatkan penghasilan yang tinggi. Kemudian pada tingkat makro yaitu penduduk dengan tingkat kesehatan yang baik merupakan masukan (input) penting untuk menurunkan kemiskinan, pertumbuhan ekonomi, dan pembangunan ekonomi jangka panjang.

Perbaikan dalam status gizi tenaga kerja akan meningkatkan efisiensi kerja melalui peningkatan kemampuan individualnya. Pengaruh dari program kesehatan serta gizi terhadap penduduk usia muda akan terlihat pada peningkatan GNP (Gross National Product) melalui pertumbuhan ekonomi, yakni dengan bertambahnya tingkat partisipasi angkatan kerja dan secara tidak langsung melalui tingkat partisipasi dalam dunia pendidikan (Tjiptoherijanto, 1994). Sebaliknya, pendapatan perkapita penduduk juga dapat mempengaruhi status gizi karena jika pendapatan yang tinggi maka status gizi menjadi baik sehingga menurunkan angka kesakitan dan kematian, pendapatan yang rendah akan menimbulkan status gizi yang buruk sehingga meningkatnya angka kesakitan dan kematian (Apriliana \& L. Rahma, 2017).

Kurangnya pelayanan dasar hingga masih banyak kemiskinan dan kelaparan merupakan salah satu masalah yang belum teratasi sampai dengan masa MDGs berakhir. Untuk mengatasi permasalahan tersebut, diputuskan untuk lebih berfokus kepada permasalahan stunting pada anak. Stunting secara inklusif disebutkan dalam agenda MDGs pada tujuan pertama dan SDGs pada tujuan kedua (tabel 1), namun juga terkait pada tujuan-tujuan lainnya.

\section{METODE}

Jenis data yang digunakan adalah data cross section. Data yang digunakan dalam penelitian ini merupakan data sekunder yang bersifat tahunan. Data 
sekunder yang dianalisis dalam penelitian ini adalah data Riset Kesehatan Dasar (Riskesdas) tahun 2013 dan tahun 2018. Hal ini dilakukan untuk melihat perbedaan dan perubahan prevalensi stunting dari masa MDGs ke masa SDGs Data tersebut melibatkan rumah tangga di 33 provinsi di Indonesia sebagai populasi. Sampel rumah tangga diambil dari 497 kabupaten/kota. Jumlah sampel sebanyak 294.959 rumah tangga dan 1.027.763 individu pada tahun 2013 dan rumah tangga di 34 provinsi diambil dari 514 kabupaten/kota dengan jumlah sampel sebanyak 295.720 rumah tangga dan 1.091.528 individu pada tahun 2018.
Untuk menentukan faktor penentu dilakukan dengan analisis regresi logistik dengan menguji logistic binary regression (logit). Spesifikasi model ekonometrik dan deskripsi data yang digunakan dalam penelitian ini adalah:

$$
\begin{aligned}
\operatorname{Ln}(\mathrm{St} /(1-\mathrm{St})= & \beta_{0}+\beta_{1} \mathrm{AB}+\beta_{2} \mathrm{SAN}+\beta_{3} \mathrm{ALK}+\beta_{4} \mathrm{JKN} \\
& +\beta_{5} \mathrm{TT}+\beta_{6} \mathrm{ITbk}+\beta_{7} \mathrm{IPp}+\beta_{8} \mathrm{BBSI}+ \\
& \beta_{9} \mathrm{P}+\varepsilon
\end{aligned}
$$

dimana:

$\mathrm{Y} \quad=$ variabel dependen yaitu kejadian balita stunting

$\beta 0=$ intersep $/$ konstan

$\beta 1-\beta \mathrm{n}=$ koefisien regresi

\begin{tabular}{|c|c|c|}
\hline Keterangan & MDGs (2000-2015) & SDGs (2016-2030) \\
\hline Tujuan 1 & $\begin{array}{l}\text { Menanggulangi kemiskinan } \\
\text { dan kelaparan }\end{array}$ & $\begin{array}{l}\text { Tanpa Kemiskinan, tidak ada kemiskinan dalam bentuk apapun di seluruh } \\
\text { penjuru dunia }\end{array}$ \\
\hline Tujuan 2 & $\begin{array}{l}\text { Mencapai pendidikan dasar } \\
\text { untuk semua, }\end{array}$ & $\begin{array}{l}\text { Tanpa Kelaparan, tidak ada lagi kelaparan, mencapai ketahanan pangan, } \\
\text { perbaikan nutrisi, serta mendorong budidaya pertanian yang berkelanjutan }\end{array}$ \\
\hline Tujuan 3 & $\begin{array}{l}\text { Mendorong kesetaraan gender } \\
\text { dan pemberdayaan perempuan }\end{array}$ & $\begin{array}{l}\text { Kesehatan yang Baik dan Kesejahteraan Menjamin kehidupan yang sehat serta } \\
\text { mendorong kesejahteraan hidup untuk seluruh masyarakat di segala umur }\end{array}$ \\
\hline Tujuan 4 & $\begin{array}{l}\text { Menurunkan angka kematian } \\
\text { anak }\end{array}$ & $\begin{array}{l}\text { Pendidikan Berkualitas, Menjamin pemerataan pendidikan yang berkualitas dan } \\
\text { meningkatkan kesempatan belajar untuk semua orang }\end{array}$ \\
\hline Tujuan 5 & Meningkatkan kesehatan ibu & $\begin{array}{l}\text { Kesetaraan Gender, mencapai kesetaraan gender dan memberdayakan kaum ibu } \\
\text { dan perempuan }\end{array}$ \\
\hline Tujuan 6 & $\begin{array}{l}\text { Memerangi } \quad \text { HIV/AIDS, } \\
\text { malaria dan penyakit menular } \\
\text { lainnya }\end{array}$ & $\begin{array}{l}\text { Air Bersih dan Sanitasi, menjamin ketersediaan air bersih dan sanitasi yang } \\
\text { berkelanjutan untuk semua orang }\end{array}$ \\
\hline Tujuan 7 & $\begin{array}{ll}\text { Memastikan } & \text { kelestarian } \\
\text { lingkungan hidup }\end{array}$ & $\begin{array}{l}\text { Energi Bersih dan Terjangkau, menjamin akses terhadap sumber energi yang } \\
\text { terjangkau, terpercaya, berkelanjutan dan modern untuk semua orang }\end{array}$ \\
\hline Tujuan 8 & $\begin{array}{l}\text { Mengembangkan kemitraan } \\
\text { global untuk pembangunan }\end{array}$ & $\begin{array}{l}\text { Pertumbuhan Ekonomi dan Pekerjaan yang Layak, mendukung perkembangan } \\
\text { ekonomi yang berkelanjutan, lapangan kerja yang produktif serta pekerjaan yang } \\
\text { layak untuk semua orang }\end{array}$ \\
\hline Tujuan 9 & & $\begin{array}{l}\text { Industri, Inovasi dan Infrastruktur, membangun infrastruktur yang berkualitas, } \\
\text { mendorong peningkatan industri yang berkelanjutan serta mendorong inovasi }\end{array}$ \\
\hline Tujuan 10 & & $\begin{array}{l}\text { Mengurangi Kesenjangan, mengurangi ketidaksetaraan baik di dalam sebuah } \\
\text { negara maupun di antara negara-negara di dunia }\end{array}$ \\
\hline Tujuan 11 & & $\begin{array}{l}\text { Keberlanjutan Kota dan Komunitas, membangun kota-kota serta pemukiman } \\
\text { yang berkualitas, aman dan bekelanjutan }\end{array}$ \\
\hline Tujuan 11 & & $\begin{array}{l}\text { Konsumsi dan Produksi Bertanggung Jawab, menjamin keberlangsungan } \\
\text { konsumsi dan pola produksi }\end{array}$ \\
\hline Tujuan 13 & & $\begin{array}{l}\text { Aksi Terhadap Iklim, bertindak cepat untuk memerangi perubahan iklim dan } \\
\text { dampaknya }\end{array}$ \\
\hline Tujuan 14 & & $\begin{array}{l}\text { Kehidupan bawah laut, melestarikan dan menjaga keberlangsungan laut dan } \\
\text { kehidupan sumber daya laut untuk perkembangan yang berkelanjutan }\end{array}$ \\
\hline Tujuan 15 & & $\begin{array}{l}\text { Kehidupan di Darat, melindungi, mengembalikan, dan meningkatkan } \\
\text { keberlangsungan pemakaian ekosistem darat, mengelola hutan secara } \\
\text { berkelanjutan, mengurangitanah tandus serta tukar guling tanah }\end{array}$ \\
\hline Tujuan 16 & & $\begin{array}{l}\text { Institusi Peradilan yang Kuat dan Kedamaian, meningkatkan perdamaian } \\
\text { termasuk masyarakat untuk pembangunan berkelanjutan, menyediakan akses } \\
\text { untuk keadilan bagi semua orang termasuk lembaga dan bertanggung jawab } \\
\text { untuk seluruh kalangan }\end{array}$ \\
\hline Tujuan 17 & & $\begin{array}{l}\text { Kemitraan untuk Mencapai Tujuan, Memperkuat implementasi dan } \\
\text { menghidupkan kembali kemitraan global untuk pembangunan yang } \\
\text { berkelanjutan }\end{array}$ \\
\hline
\end{tabular}

$\mathrm{AB} \quad=$ akses air bersih

Tabel 1. Tujuan MDGS dan SDGs 


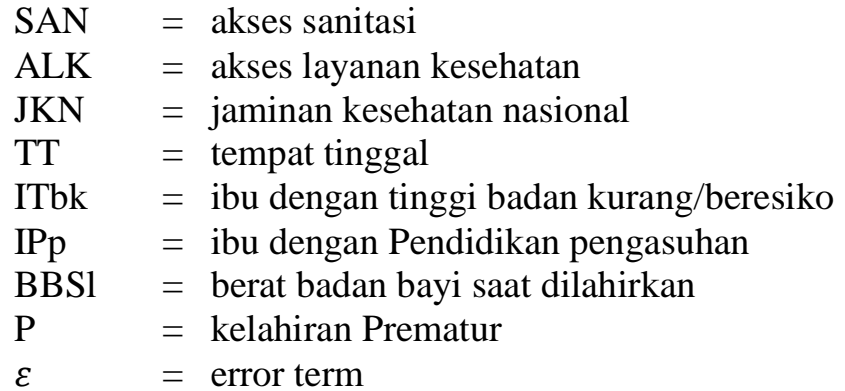

Adapun pengukuran dari variabel yang diamati dalam penelitian ini dapat dilihat pada tabel 2 .

\section{HASIL DAN PEMBAHASAN}

Hasil dan pembahasan dapat menampilkan datadata berupa tabel maupun gambar. Hasil harus didukung oleh referensi terkait ataupun dapat membandingkan dengan penelitian sebelumnya.

\section{Akses Air Bersih}

Pemakaian air bersih ini digunakan untuk keperluan minum, masak, kebersihan pribadi dan mencuci menurut kriteria Health

Tabel 2. Pengukuran Variabel Penelitian

\begin{tabular}{|c|c|c|c|}
\hline \multicolumn{2}{|r|}{ Variabel } & Defenisi Operasional & \multirow{2}{*}{$\begin{array}{l}\quad \text { Satuan/Ukuran Variabel } \\
1=\text { Stunting } \\
0=\text { Tidak Stunting }\end{array}$} \\
\hline St & $\begin{array}{l}\text { Kejadian Balita } \\
\text { Stunting }\end{array}$ & $\begin{array}{l}\text { Balita yang mempunyai } \mathrm{z} \text { skor tinggi badan menurut umur } \\
(\mathrm{TB} / \mathrm{U}) \text { kurang dari -2 SD terhadap total balita }\end{array}$ & \\
\hline \multicolumn{4}{|c|}{ Karakteristik Rumah Tangga } \\
\hline $\mathrm{AB}$ & Akses air bersih & $\begin{array}{l}\text { Jumlah pemakaian air bersih rumah tangga untuk keperluan } \\
\text { minum, masak, kebersihan pribadi dan mencuci ( Kriteria } \\
\text { Health Concern, Howard 2013) }\end{array}$ & $\begin{array}{l}1=<20-49,9 \text { liter/orang/hari } \\
0=\geq 20-49,9 \text { liter/orang/hari }\end{array}$ \\
\hline SAN & Akses sanitasi & Rumah tangga dengan penampungan air limbah tertutup & $\begin{array}{l}1=\text { Terbuka } \\
0=\text { Tertutup }\end{array}$ \\
\hline ALK & $\begin{array}{l}\text { Akses layanan } \\
\text { kesehatan }\end{array}$ & $\begin{array}{l}\text { Pengetahuan Rumah Tangga terhadap keberadaan puskesmas/ } \\
\text { pustu/ pusling/ bidan desa yang terdekat }\end{array}$ & $\begin{array}{l}1=\text { Tidak tahu } \\
0=\text { Tahu }\end{array}$ \\
\hline JKN & $\begin{array}{l}\text { Jaminan kesehatan } \\
\text { nasional }\end{array}$ & $\begin{array}{l}\text { Sumber Pembiayaan Persalinan di Fasilitas Pelayanan } \\
\text { Kesehatan pada Perempuan Umur 10-54 Tahun }\end{array}$ & $\begin{array}{l}1=\text { Diluar biaya pemerintah } \\
0=\text { Biaya pemerintah }\end{array}$ \\
\hline TT & Tempat Tinggal & Wilayah tempat tinggal keluarga & $\begin{array}{l}1=\text { Pedesaan } \\
0=\text { Perkotaan }\end{array}$ \\
\hline \multicolumn{4}{|c|}{ Karakteristik Ibu } \\
\hline ITbk & $\begin{array}{l}\text { Ibu dengan tinggi } \\
\text { badan kurang / } \\
\text { beresiko }\end{array}$ & Ibu dengan tinggi badan kurang dari $150 \mathrm{~cm}$ & $\begin{array}{l}1=<150 \mathrm{~cm} \\
0=\geq 150 \mathrm{~cm}\end{array}$ \\
\hline IPp & $\begin{array}{l}\text { Ibu dengan } \\
\text { Pendidikan } \\
\text { pengasuhan }\end{array}$ & $\begin{array}{l}\text { Kepemilikan buku Kesehatan Ibu dan Anak (KIA) pada ibu yang } \\
\text { sedang hamil. Status kepemilikan berdasarkan pengakuan } \\
\text { Dan observasi fisik buku KIA }\end{array}$ & $\begin{array}{l}1=\text { Tidak memiliki } \\
0=\text { Memiliki }\end{array}$ \\
\hline \multicolumn{4}{|c|}{ Karakteristik Anak } \\
\hline BBS1 & $\begin{array}{l}\text { Berat badan bayi } \\
\text { saat dilahirkan }\end{array}$ & $\begin{array}{l}\text { Berat badan bayi saat dilahirkan. Berat lahir normal berkisar } \\
2500-4000 \text { gram. BBLR (Berat Badan Lahir Rendah adalah < } \\
2500 \text { gram) (Kementerian Kesehatan, 2010) }\end{array}$ & $\begin{array}{l}1=\text { BBLR } \\
0=\text { Tidak BBLR }\end{array}$ \\
\hline $\mathrm{P}$ & Kelahiran Prematur & Bayi lahir tidak pada masa kelahiran normal atau kurang bulan & $\begin{array}{l}1=<37 \text { minggu } \\
0=37 \text { minggu }\end{array}$ \\
\hline
\end{tabular}

Concern adalah pemakaian air >20-49,9 liter/orang/hari.

Jika di lihat menurut provinsi, pemakaian air bersih menuju akses optimal (>20-49,9 liter/orang/hari) rata-rata mengalami peningkatan pada periode tahun 2013-2018 (gambar 1). Pada tahun 2013, 92,19\% rumah tangga Indonesia telah melakukan pemakaian air bersih sesuai kriteria Health Concern dan meningkat menjadi $97,05 \%$ pada tahun 2018 .
Hal ini mengindikasikan bahwa terjadi peningkatan pembangunan sarana air bersih di Indonesia. Daerah yang mengalami penurunan adalah Provinsi Sumatera Selatan, Kepulauan Riau, Bangka Belitung, Kalimantan Barat, Kalimantan Timur, Sulawesi Tengah, Gorontalo, Sulawesi Barat dan Papua Barat. 


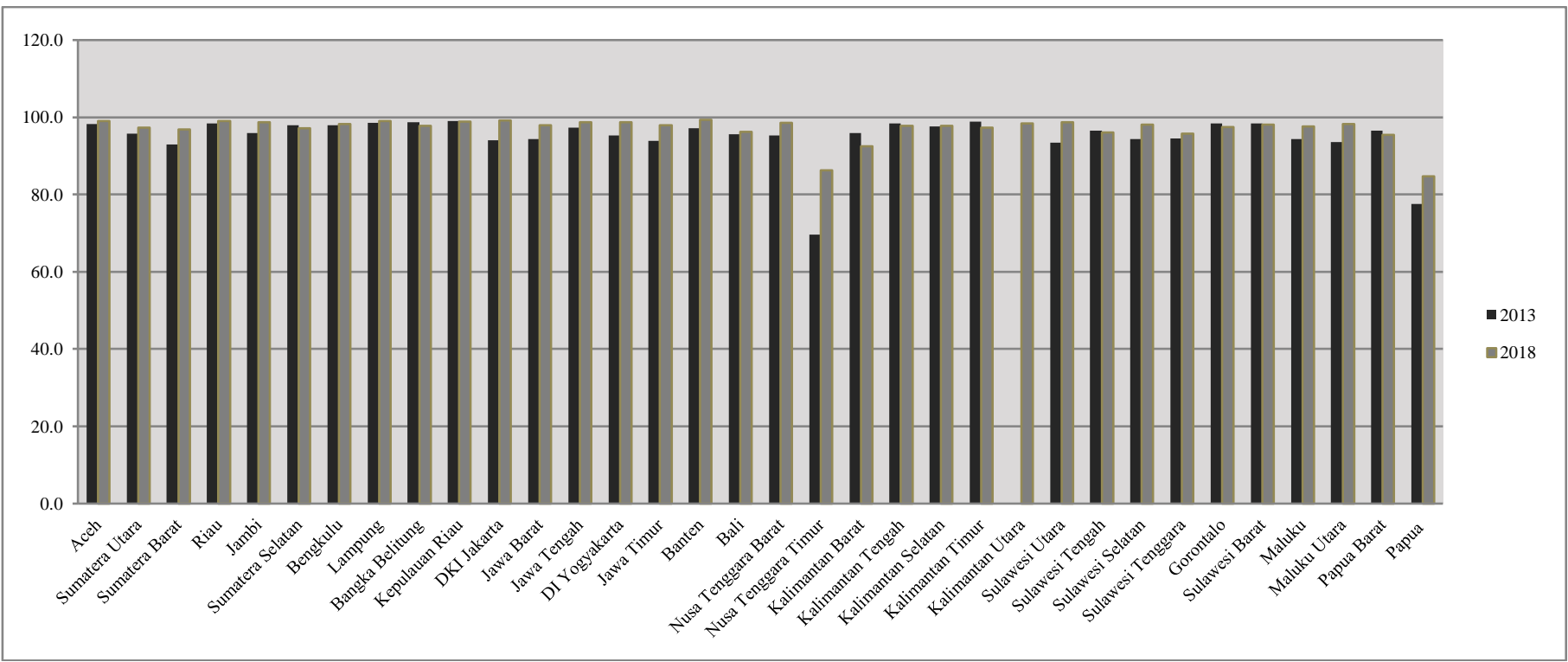

Gambar 1. Pemakaian air bersih rumah tangga Indonesia (>20-49,9 liter/orang/hari)

Sumber Data: Laporan Riskesdas tahun 2013 dan 2018

\section{Akses Sanitasi}

Tempat penampungan akhir air limbah dan sampah baik dari kamar mandi maupun dapur rumah tangga sesuai dengan kriteria JMP WHO-Unicef tahun 2006 adalah penampungan tertutup.

Jika di lihat menurut provinsi, sarana pembuangan air limbah rumah tangga yang baik (tertutup) rata-rata mengalami peningkatan pada periode tahun 2013-2018. Pada tahun 2013, 14,58\% rumah tangga Indonesia telah memiliki sarana sanitasi sesuai kriteria JMP WHOUnicef dan meningkat menjadi 15,74\% pada tahun 2018. Hal ini mengindikasikan bahwa terjadi peningkatan pembangunan sarana sanitasi di Indonesia namun masih sangat jauh dari yang diharapkan.

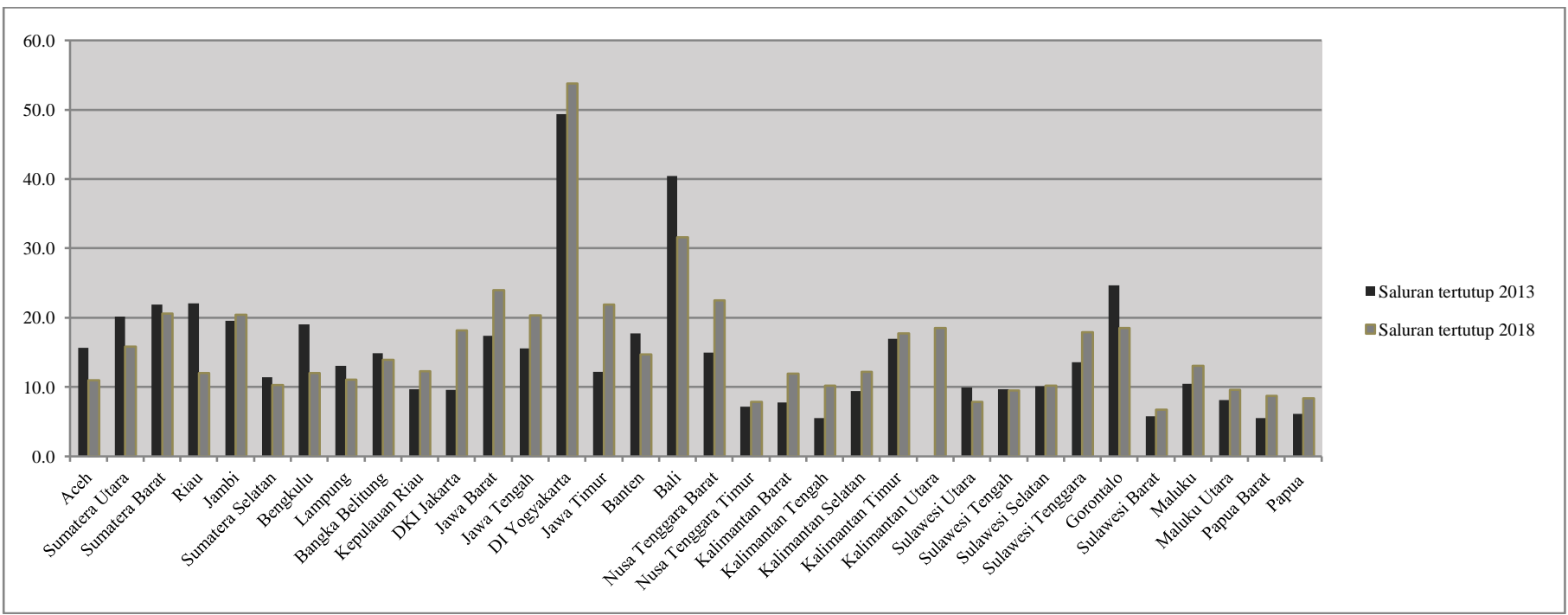

Gambar 2.Sarana Pembuangan Air Limbah Rumah Tangga Indonesia (Saluran tertutup)

Sumber Data: Laporan Riskesdas tahun 2013 dan 2018

\section{Akses Layanan Kesehatan}

Pada tahun 2018, terdapat 37,03\% rumah tangga Indonesia yang telah memiliki akses mudah terhadap fasilitas kesehatan seperti rumah sakit, puskesmas dan klinik/praktek dokter selebihnya memiliki akses sulit dan sangat sulit. Daerah yang memiliki akses sangat sulit paling besar antara lain Provinsi Nusa Tenggara Timur dan Papua.

\section{Jaminan Kesehatan Nasional}

Pada penelitiaan ini menganalisa pembiayaan kesehatan yang meliputi pembiayaan persalinan. Sumber biaya yang biasanya digunakan ibu saat bersalin di fasilitas kesehatan terdiri dari BPJS/KIS, asuransi swasta, biaya kantor, biaya orang lain, biaya sendiri, Jampersal atau Jamperda.

Jika di lihat menurut provinsi, rumah tangga Indonesia yang telah dibiayai oleh pemerintah terhadap kesehatan terutama persalinan rata-rata mengalami 
Sri Widari et al., Faktor Penentu Stunting: Analisis Komparasi Masa Millenium Development Goals (MDGs) dan Sustainable Development Goals (SDGs) di Indonesia

peningkatan pada periode tahun 2013-2018. Pada tahun 2013, 53,85\% rumah tangga Indonesia telah dibiayai pemerintah dan meningkat menjadi $56,66 \%$ pada tahun
2018. Daerah yang mengalami penurunan bantuan terhadapa fasilitas kesehatan terutama persalinan terbesar adalah Jawa Timur, Bali dan Papua (gambar 3).

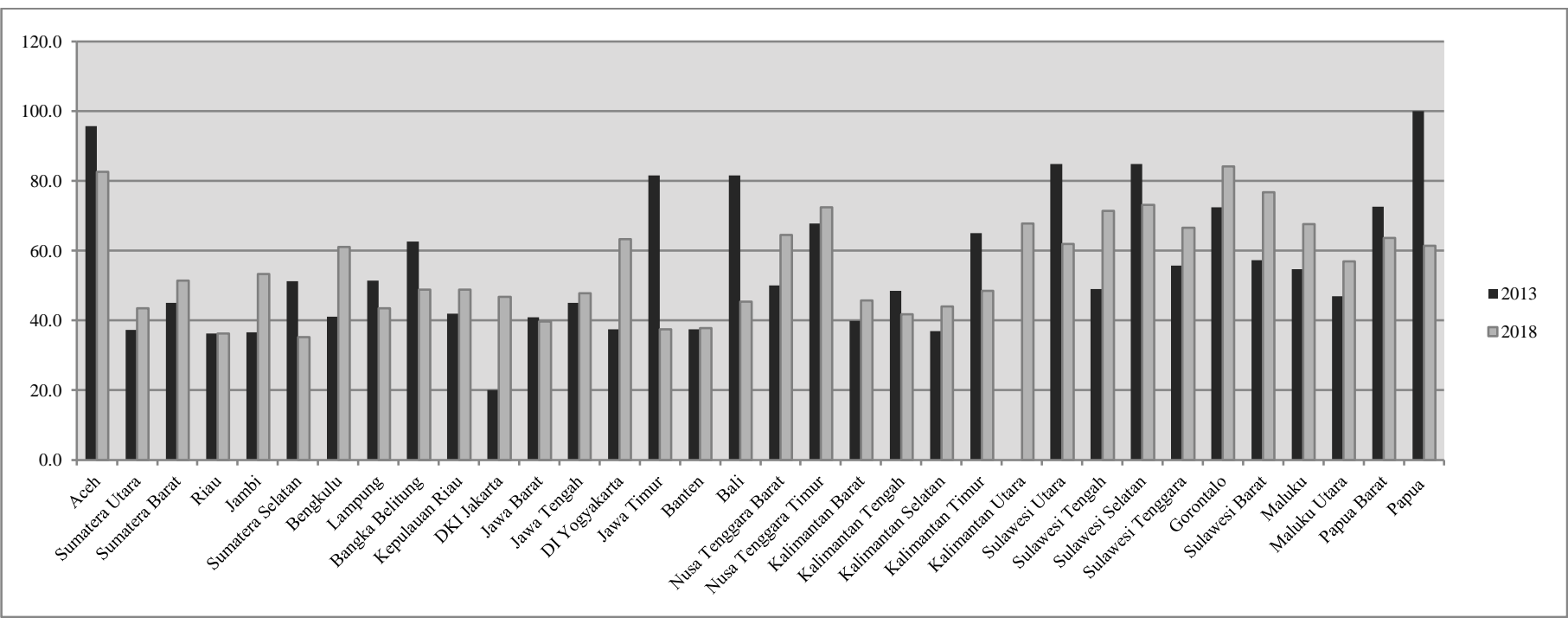

Gambar 3. Pembiayaan Persalinan Rumah Tangga Indonesia (biaya pemerintah)

Sumber Data: Laporan Riskesdas tahun 2013 dan 2018

\section{Tempat Tinggal}

Tempat tinggal dalam penelitian ini merupakan wilayah tempat tinggal rumah tangga yang memiliki balita, sehingga nantinya dapat diketahui pengaruh wilayah tempat tinggal itu sendiri terhadap kejadian stunting. Wilayah tempat tinggal dibedakan menjadi perdesaan dan perkotaan. Sebagaimana diketahui, karakteristik masyarakat perdesaan dan perkotaan bisa begitu berbeda akibat adanya beberapa perbedaan signifikan terkait cara hidup sehari-hari dan sistem sosialnya.

\section{Ibu dengan Tinggi Badan Berisiko}

Tinggi badan orang tua juga berkaitan dengan kejadian stunting balita. Dalam penelitian ini yang diperhatikan adalah hubungan antara tinggi ibu dengan kejadian stunting. Kemungkinan besar dari ibu yang tinggi badan kurang akan melahirkan bayi yang pendek pula. Ibu yang pendek memiliki gen dalam kromosom yang membawa sifat pendek sehingga memperbesar peluang anak mewarisi gen tersebut dan tumbuh menjadi stunting. Namun bila ibu pendek akibat faktor masalah gizi saat pertumbuhannya, maka kejadian stunting pada anaknya dapat dicegah sejak dini.

Beberapa penelitian terdahulu menghasilkan penemuan bahwa ibu yang tinggi badan kurang merupakan faktor yang berhubungan dengan kejadian stunting. Salah satunya adalah menyatakan bahwa ibu di Mesir yang memiliki tinggi badan $<150 \mathrm{~cm}$ lebih berisiko memiliki anak stunting dari pada ibu yang tinggi badannya $>150 \mathrm{~cm}$ (Zottarelli et al., 2007). Namun beberapa penelitian lainnya menyatakan bahwa ibu yang tinggi badannya kurang tidak akan berpengaruh terhadap tinggi anaknya.

\section{Ibu dengan Pendidikan Pengasuhan}

Pengetahuan terhadap stunting ini diperlukan mulai dari ketika ibu hamil sampai dengan bayi dilahirkan. Pada penelitian ini, variabel pendidikan pengasuhan ibu dilihat dari kepemilikan buku Kesehatan Ibu dan Anak (KIA) pada ibu yang sedang hamil. Status kepemilikan dilihat dari hasil observasi oleh Riskesdas. Buku KIA berisikan tentang pencatatan dan pemantauan serta merupakan penyuluhan (edukasi) kesehatan ibu dan anak mulai dari saat ibu hamil sampai dengan anak yang dilahirkan berusia 5 tahun.

Jika di lihat menurut provinsi, kepemilikan buku Kesehatan Ibu dan Anak (KIA) pada ibu yang sedang hamil pada rumah tangga Indonesia mengalami peningkatan pada periode tahun 2013-2018. Pada tahun 2013, 36,66\% rumah tangga Indonesia telah memiliki buku KIA serta dapat menunjukkannya dan meningkat pada tahun 2018 menjadi 63,55\%. Namun pada tahun 2018, masih terdapat $26,71 \%$ lagi yang belum atau tidak memiliki buku KIA (gambar 4).

\section{Berat Badan Bayi saat Dilahirkan}

Selain dari panjang badan, stunting pada balita dapat juga dilihat dari berat badan saat dilahirkan. Berat badan lahir rendah (BBLR) dapat menjadi penyebab bayi memiliki kemungkinan stunting menjadi lebih besar. Terjadinya BBLR dapat disebabkan oleh status gizi ibu sebelum dan ketika hamil. Pada penelitian ini, kriteria berat badan diambil dari aturan Kementerian Kesehatan tahun 2010 yang menyatakan berat lahir normal adalah berkisar 2500-4000 gram. Maka termasuk BBLR bila berat badan lahir bayi < 2500 gram. 
Sri Widari et al., Faktor Penentu Stunting: Analisis Komparasi Masa Millenium Development Goals (MDGs) dan Sustainable Development Goals (SDGs) di Indonesia

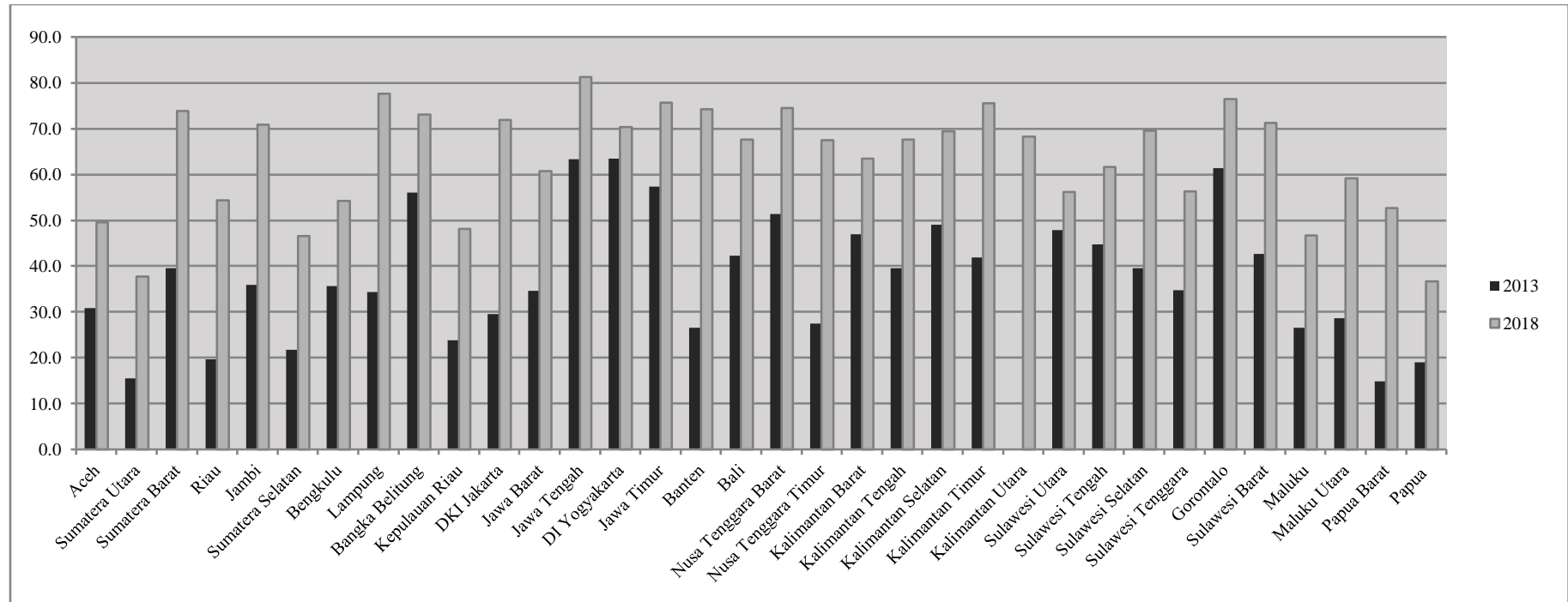

Gambar 4. Kepemilikan Buku KIA Rumah Tangga Indonesia (memiliki dan bisa menunjukkan) Sumber Data: Laporan Riskesdas tahun 2013 dan 2018

\section{Kelahiran Prematur}

Sebagaimana penelitian yang menyatakan bahwa kelahiran prematur dapat menyebabkan risiko bayi menjadi stunting dua kali lebih besar dari pada bayi dengan waktu kelahiran normal. Prematur adalah kelahiran yang terjadi sebelum minggu ke-37 atau lebih awal dari hari perkiraan lahir.
Pada tahun 2018, terdapat 32,25\% rumah tangga Indonesia yang memiliki bayi yang lahir secara prematur (terjadi sebelum minggu ke-37 atau lebih awal dari hari perkiraan lahir). Daerah yang memiliki jumlah bayi berkelahiran prematur paling besar antara lain Provinsi Aceh $(51,4 \%)$, Sumatera Utara $(56,6 \%)$, Riau $(51,3 \%)$, Sulawesi Utara (50,5\%), Maluku (51,3\%) dan Maluku Utara $(56,2 \%)$ (gambar 5).

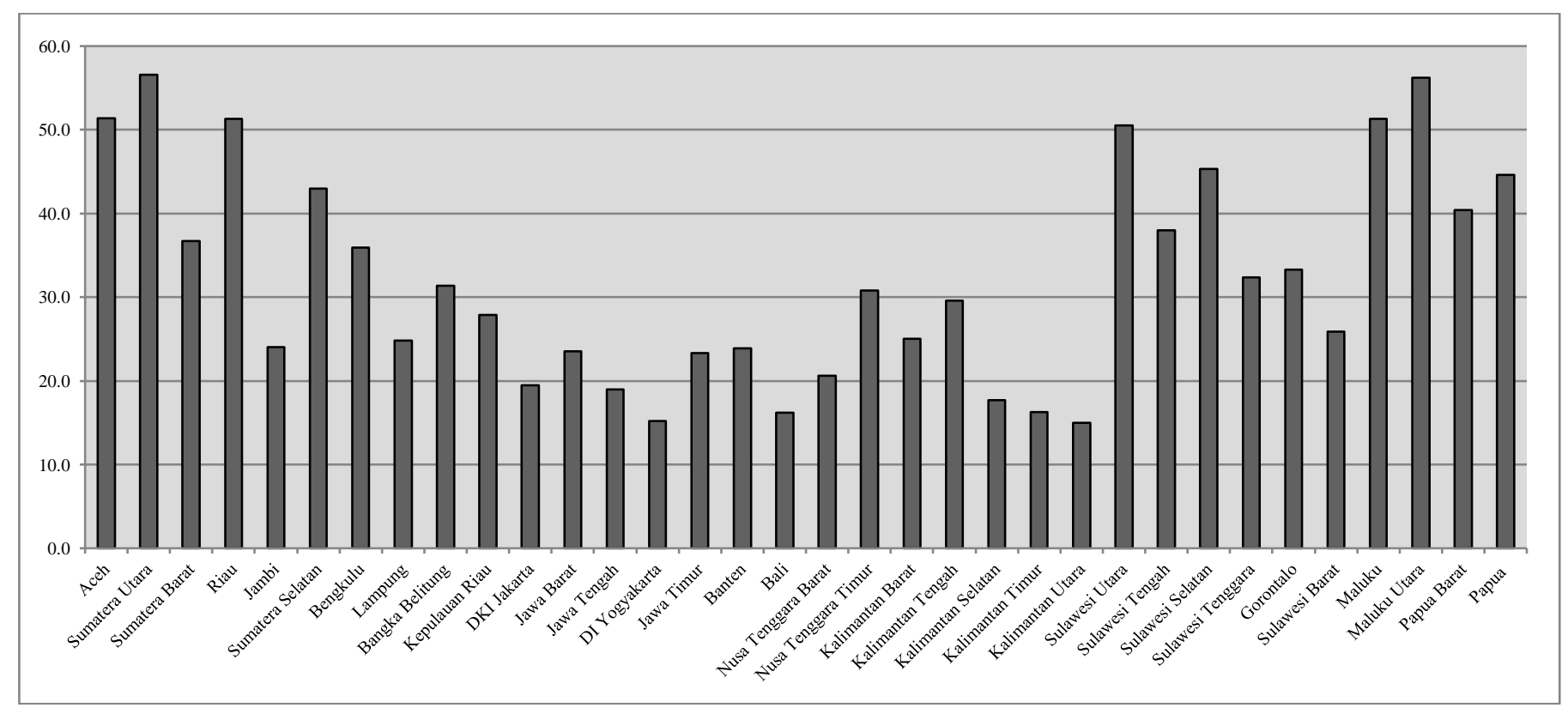

Gambar 5. Kelahiran Prematur Bayi pada Rumah Tangga Indonesia

Sumber Data: Laporan Riskesdas 2018

\section{Temuan Empiris}

Dari hasil pengolahan data diperoleh hasil uji asumsi logit variabel stunting terhadap variabel independen seperti terlihat pada tabel 3. Ada sembilan variabel yang di teliti yaitu akses air bersih, akses sanitasi, akses layanan kesehatan, jaminan kesehatan dan tempat tinggal untuk melihat karakteristik rumah tangga. Kemudian ibu dengan tinggi kurang dan ibu dengan pendidikan pengasuhan untuk melihat karakteristik ibu. Sedangkan untuk melihat karakteristik anak adalah berat badan anak saat dilahirkan dan kelahiran prematur. 
Sri Widari et al., Faktor Penentu Stunting: Analisis Komparasi Masa Millenium Development Goals (MDGs) dan Sustainable Development Goals (SDGs) di Indonesia

Tabel 3. Hasil Estimasi Model Penelitian

\begin{tabular}{|c|c|c|c|c|c|c|c|c|c|c|}
\hline \multirow{2}{*}{$\begin{array}{c}\text { Variabel } \\
\text { Penelitian }\end{array}$} & \multicolumn{2}{|c|}{ B } & \multicolumn{2}{|c|}{ S.E } & \multicolumn{2}{|c|}{ Wald } & \multicolumn{2}{|c|}{$d f$} & \multicolumn{2}{|c|}{ Sig. } \\
\hline & 2013 & 2018 & 2013 & 2018 & 2013 & 2018 & 2013 & 2018 & 2013 & 2018 \\
\hline Konstanta $\left(\beta_{0}\right)$ & $-0,936$ & $-1,271$ & 0,040 & 0,026 & 560,609 & 6,465 & 1 & 1 & 0,000 & 0,011 \\
\hline $\mathrm{AB}$ & 0,077 & 0,066 & 0,029 & 0,031 & 7,102 & 6,009 & 1 & 1 & 0,008 & 0,014 \\
\hline SAN & 0,126 & 0,075 & 0,037 & 0,120 & 11,629 & 0,454 & 1 & 1 & 0,001 & 0,500 \\
\hline ALK & 0,020 & 0,081 & 0,052 & 0,023 & 0,146 & 0,147 & 1 & 1 & 0,703 & 0,712 \\
\hline JKN & 0,094 & 0,008 & 0,031 & 0,023 & 1,153 & 87,224 & 1 & 1 & 112 & 0,000 \\
\hline $\mathrm{T}$ & 0,203 & 0,219 & 0,027 & 0,024 & 55,074 & 570,532 & 1 & 1 & 0,000 & 0,000 \\
\hline ITbk & 0,421 & 0,563 & 0,029 & 0,025 & 215,50 & 0,813 & 1 & 1 & 0,000 & 0,367 \\
\hline IP & 0,043 & 0,023 & 0,032 & 0,045 & 1,837 & 181,472 & 1 & 1 & 0,175 & 0,000 \\
\hline BBS1 & 0,510 & 0,610 & 0,056 & 0,025 & 81,612 & 3,851 & 1 & 1 & 0,000 & 0,049 \\
\hline & 0,097 & 0,050 & 0,029 & 0,035 & 11,337 & 1351,505 & 1 & 1 & 0,001 & 0,000 \\
\hline
\end{tabular}

Sumber Data : Hasil Pengolahan Data Riskesdas Tahun 2013 dan 2018

Hasil uji asumsi logit dari persamaan diatas menunjukkan bahwa:

1. Peluang rumah tangga yang tidak memiliki akses air bersih memiliki balita stunting lebih tinggi 7,7\% (2013) dan 6,6\% (2018) dibandingkan rumah tangga yang memiliki akses air bersih. Rumah tangga yang diberikan akses terhadap air bersih dengan tingkat konsumsi < 20-49,9 liter/orang/hari meningkatkan resiko balita stunting sebesar 1,080 kali (2013) dan 1,068 kali (2018) lebih besar dari rumah tangga dengan tingkat konsumsi $\geq 20-49,9$ liter/orang/hari.

2. Peluang rumah tangga yang tidak memiliki akses sanitasi memiliki balita stunting lebih tinggi $12,6 \%$ (2013) dan 7,5\% (2018) dibandingkan rumah tangga yang memiliki akses sanitasi yang baik Rumah tangga yang memiliki akses terhadap sanitasi yang terbuka, maka resiko balita stuntingnya menjadi 1,134 kali (2013) dan 1,078 kali (2018) lebih tinggi dari rumah tangga dengan sanitasi yang tertutup.

3. Akses layanan kesehatan pada penelitian ini memiliki pengaruh yang positif namun tidak signifikan terhadap kejadian stunting. Rumah tangga dengan akses layanan kesehatan memiliki balita stunting dengan p-value sebesar 0,347>0,05 (data Riskesdas 2013) dan 0,299>0,05 (data Riskesdas 2018). Hal ini berarti bahwa akses layanan kesehatan tidak akan berpengaruh pada kejadian stunting balita.

4. Untuk variabel jaminan kesehatan nasional hasil studi memperlihatkan bahwa variabel ini memiliki pengaruh yang positif namun tidak signifikan terhadap kejadian stunting dengan p-value sebesar $0,056>0,05$ (data Riskesdas 2013) dan 0,082 > 0,05 (data Riskesdas 2018). Dimana hal ini berarti bahwa jaminan kesehatan nasional tidak akan berpengaruh pada kejadian stunting balita.

5. Peluang rumah tangga yang tinggal di perdesaan memiliki balita stunting lebih tinggi 20,3\% (2013) dan 21,9\% (2018) dibandingkan rumah tangga yang tinggal di perkotaan. Rumah tangga yang pada saat persalinan memiliki tempat tinggal di perdesaan memiliki probabilitas balita stunting 1,226 kali (2013) dan 1,245 kali (2018) lebih tinggi dari rumah tangga yang berdomisili di perkotaan.

6. Peluang ibu dengan tinggi badan kurang memiliki balita stunting lebih tinggi 42,1\% (2013) dan 56,3\% (2018) dibandingkan ibu dengan tinggi badan lebih dari $150 \mathrm{~cm}$. Ibu yang pada saat persalinan memiliki tinggi badan kurang dari $150 \mathrm{~cm}$ memiliki probabilitas balita stunting 1,523 kali (2013) dan 1,755 kali (2018) lebih besar dari ibu dengan tinggi badan lebih dari $150 \mathrm{~cm}$.

7. Ibu dengan pendidikan pengasuhan memiliki pengaruh yang positif namun tidak signifikan terhadap kejadian stunting dimana ibu dengan pendidikan pengasuhan memiliki balita stunting dengan p-value sebesar 0,357 >0,05 (data Riskesdas 2013) dan 0,367>0,05 (data Riskesdas 2018). Hal ini berarti bahwa ibu dengan pendidikan pengasuhan tidak akan berpengaruh pada kejadian stunting balita.

8. Peluang balita yang berat badan lahir rendah (BBLR) menjadi balita stunting 51\% (2013) dan 61\% (2018) dibandingkan balita yang tidak BBLR. Balita yang pada saat persalinan memiliki berat badan kurang dari 2500 gram akan meningkatkan resiko balita stunting 1,665 kali (2013) dan 1,841 kali (2018) lebih tinggi dari balita dengan berat badan berkisar 2500 s/d 4000 gram.

9. Peluang balita yang lahir prematur menjadi balita stunting lebih tinggi 9,7\% (2013) dan 5\% (2018) dibandingkan balita yang lahir normal pada waktunya. Balita yang pada saat persalinan memiliki kelahiran prematur atau masa kehamilan kurang dari 37 minggu berpotensi meningkatkan balita stunting 1,102 kali (2013) dan 1,051 kali (2018) lebih besar dari balita yang lahir normal atau masa kehamilan lebih dari 37 minggu.

\section{SIMPULAN}

Dari penelitian ini yang menggunakan data Riset Kesehatan Dasar (Riskesdas) tahun 2013 dan 2018 
mewakili keadaan stunting di Indonesia pada masa MDGs dan SDGs menghasilkan kajian bahwa variabel berat badan balita saat dilahirkan, ibu dengan tinggi badan kurang, tempat tinggal, akses sanitasi, akses air bersih, ibu dengan pendidikan pengasuhan, akses layanan kesehatan, jaminan kesehatan nasional dan kelahiran prematur memiliki hubungan yang positif terhadap kejadian balita stunting.

Variabel yang merupakan determinan (faktor penentu) yang memiliki hubungan bermakna (signifikan) terhadap kejadian balita stunting hasil regresi logistik pada penelitian ini adalah berat badan balita saat dilahirkan, ibu dengan tinggi badan kurang, tempat tinggal, akses sanitasi, akses air bersih dan kelahiran prematur.

Untuk dapat mengurangi prevalensi stunting sesuai pencapaian target SDG's 2030 yang merupakan lanjutan tujuan dari MDGs perlu adanya strategi pemerintah agar tepat dan cepat melakukan intervensi terhadap penurunan jumlah kejadian berat badan lahir rendah, penurunan jumlah ibu dengan tinggi badan kurang, pemerataan pembangunan terkait penurunan stunting di wilayah kota dan desa, peningkatan akses sanitasi dan air bersih serta penurunan jumlah kelahiran bayi prematur.

\section{DAFTAR PUSTAKA}

Apriliana, W. F dan L. L. Rahma. (2017). Faktor-Faktor Yang Berhubungan Dengan Status Gizi Balita yang Mengikuti Tfe di Kabupaten Sukoharjo. Media Publikasi Penelitian, Volume 15, No.1.

Bappenas. (2018). Cegah Stunting di 1000 Hari Pertama Kehidupan Investasi Bersama untuk Masa Depan Anak Bangsa. Jakarta: Bappenas.

Bappenas. (2018). Pedoman Pelaksanaan Intervensi Penurunan Stunting Terintegrasi di Kabupaten/Kota. Jakarta.

Becker, G. S. 1993. Human Capital: a theoritical and empirical analysis, with special reference to education. London: The University of Chicago Press, Ltd. 390 hal.

Buku Panduan SDGs. (2015). International NGO Forum of Indonesian Development.

Darma, D. C., Purwadi dan T. C. Wijayanti. (2020). Ekonomika Gizi: Dimensi Baru di Indonesia. Yayasan Kita Menulis. $262 \mathrm{Hal}$.

Elfindri. (2003). Ekonomi Layanan Kesehatan. Padang: Andalas University Press.

Grossman, M. (1972). On the Concept of Health Capital and the Demand for Health. Journal of Political Economy. 80 (2), 223-255.

Nutrition,G. 2016. Indonesia-Global Nutrition Report. Diakses melalui https://globalnutritionreport.org/.

Kementerian Kesehatan RI. (2016). Situasi Balita Pendek. Jakarta: Pusat Data dan Informasi Kementerian Kesehatan RI.
Lubis, A. F. (2009). Ekonomi Kesehatan. Medan: USU Press.

Mishra, N. R., S. K. Mohanty., D. Mittra., M. Shah and W. B. Meitei. (2019). Projecting stunting and wasting under alternative scenarios in Odisha, India, 2015-2030: a Lives Saved Tool (LiST) based approach. BMJ Open.

Munadhir. (2017). Ekonomi Kesehatan. Bahan Ajar FKM-UPRI. Diakses dari website https://www.researchgate.net/publication/3405933 02 tanggal 16 April 2020

Puluhulawa, I. (2013). Pengaruh Faktor Sosial Ekonomi terhadap Status Kesehatan Masyarakat di Kecamatan Palu Selatan. e-Jurnal Katalogis Vol. 1 No. $3,15-25$.

Riset Kesehatan Dasar (Riskesdas). (2013). Badan Penelitian dan Pengembangan Kesehatan tahun 2013. Jakarta: Kementerian Kesehatan RI.

Riset Kesehatan Dasar (Riskesdas). (2018). Badan Penelitian dan Pengembangan Kesehatan tahun 2019. Jakarta: Kementerian Kesehatan RI.

Tjiptoherijanto, P. (1994). Ekonomi Kesehatan. Rineka Cipta.

Todaro, Michael. P. (2000). Pembangunan Ekonomi di Dunia Ketiga. Edisi Ketujuh, Terjemahan Haris Munandar. Jakarta : Penerbit Erlangga.

UNICEF. (2019). Status Anak Dunia 2019.

WHO. 2018. WHO Child Growth Standards: length/height for age, weight for age, weight for lenght, weight for height and bodymass index for age. Geneva: Departement of Nutrition for Health and Development.

Zottarelli, L. K, T. S. Sunil and S. Rajaram. 2007. Influence of Parental and Socioeconomic Factors on Stunting in Children Under 5 Years in Egypt. Eastern Mediterranean Health Journal, Vol. 13 No. 6 